\title{
IMPACT OF THE 1988 FOREST FIRES ON THE CHEMISTRY OF GROUND WATER IN Yellowstone National PARK
}

\author{
DONALD D. RUNNELLS $\bullet$ MARY A. SIDERS \\ DEPARTMENT OF GEOLOGICAL SCIENCES \\ UNIVERSITY OF COLORADO $\bullet$ BOULDER
}

\section{$\checkmark \quad$ INTRODUCTION}

\section{PURPOSE OF THE INVESTIGATION}

In order to investigate the impact of the 1988 fires on the chemistry and water quality of shallow ground water in Yellowstone National Park, a twoyear program of sampling and analysis was begun in August, 1989. Samples from ground-water wells for which pre-fire chemical data could be obtained were selected for this study. Although it may have been anticipated that the surface waters would show some effects of fire, in terms of increased sedimentation and the addition of ash-laden runoff, the effects of the fires on ground water are less predictable. The purpose of this investigation is to determine the character and extent of these effects.

\section{$\checkmark$ RESEARCH OBJECTIVES}

The main objective of this study is to define the chemistry, transport, and fate of dissolved components entering the ground water as a result of the fires of 1988. Specific objectives that are being addressed by this investigation include:

Determination of chemical and physical properties of the ground water by means of geochemical analyses performed in the field and in the laboratory; (2) Sampling and chemical analyses of soil water (i.e. water from the unsaturated zone); (3) Leaching of ash and soil samples and chemical analysis of the aqueous extracts and comparison of leachate chemistry to that of ground water and soil water; (4) Comparison of the analytical results for the post-burn ground waters with the pre-fire data for samples collected from the same wells; (5) To assess the transport and fate of ash-derived solubles and to understand water-rock interaction as related to the chemistry of ground water. Computer modeling of the analytical data includes several different geochemical modeling programs (WATEQB, Arikan 1988; PHREEQE, Parkhurst et al. 1980; MINTEQA2, Environmental Protection Agency 1989; and NETPATH, Plummer et al. 1991).

\section{$\checkmark \quad$ HYPOTHESES TO BE TESTED}

We anticipate that the impact of the forest fires on ground-water chemistry will be more subtle than the chemical and physical effects on surface waters in the park. We envision an irregular "front" of downward-migrating leachate, containing components dissolved from the ash. The soil and regolith in this case may act much like the ion-exchange resin of a chromatography column. That is, different components will migrate with different rates of attenuation and adsorption. Some dissolved constituents will probably never reach the water table due to their uptake by plants or adsorption onto clays and other components in the regolith. 
There are several possible scenarios for the infiltration of the ash leachate, including: (1) the leachate reached the water table during the first period of ground-water recharge following the fires (i.e. during the summer of 1989) and was missed by this study, (2) the leachate was attenuated by dilution upon impact with the ground water, or the solutes were removed by sorption and/or precipitation as the leachate passed downward through the regolith, (3) the leachate has not yet reached the water table due to retardation of the solute ions as they interact with the substrate, and may still impact the ground-water chemistry, (4) the ash leachate never developed in the natural setting or never infiltrated (i.e. was removed as surface runoff).

The bulk of precipitation in Yellowstone National Park occurs as snowfall during the winter months, with infrequent scattered thunderstorms during the summer months (Dirks and Martner 1982). Ground-water recharge in the Greater Yellowstone Area therefore occurs mainly in the spring and early summer months as a result of percolation of snowmelt through the unsaturated zone. To monitor the progress of this recharge, twenty vacuum lysimeters were installed in April, 1990. By sampling the soil water collected at four different depths, we may be able to track the downward migration of ash-derived components and thereby test our hypothesis.

To test for the minimum time necessary for downward migration through the unsaturated zone to the water table, a tracer solution $(\mathrm{KBr})$ was released on the surface of the ground at two of the four sites. By measuring the concentrations of bromide in samples collected at weekly intervals, it may be possible to determine the minimum amount of time needed for the ash leachate to reach the ground water. Lateral flow rates within the saturated zone at the sampling sites have already been determined by tracer tests (Cox 1986).

\section{- RESUlts AND DisCUSSION}

Samples were analyzed for trace metals (As, $\mathrm{Ba}, \mathrm{Cu}, \mathrm{Mn}$, and $\mathrm{Pb}$ ) but showed concentrations close to or below detection limits $(.003, .005, .005, .0003$, and $.003 \mathrm{mg} / \mathrm{L}$, respectively). All samples collected in 1989 were analyzed for As by GFAA. Because every sample contained concentrations of As below the Drinking Water Standard (DWS) of $50 \mu \mathrm{g} / \mathrm{L}$ recommended by the EPA (1976); analyses for As were not performed on the samples from 1990 and 1991. Thermal waters in the Park commonly contain high levels of As (Stauffer et al. 1980), so these data suggest that thermal input is minor in the ground waters examined for this study.

Although large amounts of particulate charcoal and ash have been observed in the surface waters in Yellowstone, the low concentrations of DOC seen in all of the wells sampled to date indicate that carbonrich waters were quickly flushed through the system (prior to the inception of our study), or have not yet, or will not, reach the water table. The average concentration for DOC in rivers is $5.75 \mathrm{mg} / \mathrm{L}$ (Hem 1985), and the concentrations in ground water are normally less, due to adsorption of organics as the waters pass through the unsaturated zone. As summarized by Thurman (1985), the "...DOC in ground water ranges from 0.2 to $15 \mathrm{mg} / \mathrm{L}$ with a median concentration of $0.7 \mathrm{mg} / \mathrm{L}$. The majority of all ground waters have concentrations below 2 mg/L." Because of the relatively low concentrations of DOC measured in the ground water samples (averaging about $2 \mathrm{mg} / \mathrm{L}$ ), it was decided to sample for DOC only on an irregular basis. Additional samples for DOC were collected in the autumn of 1990. Results from analysis of the 1990 samples showed no significant changes in DOC concentrations when compared with analyses from the samples collected in 1989.

Concentrations of $\mathrm{SiO}_{2}$ were high in all groundwater samples, ranging from about 30 to $90 \mathrm{mg} / \mathrm{L}$. As determined by the mineral speciation and equilibrium model, WATEQB (Arikan 1988), all ground waters are at equilibrium with respect to silica glass and oversaturated with respect to quartz. As a result of the abundant fluoride (as much as $10 \mathrm{mg} / \mathrm{L}$ ) measured in samples from some of the wells, the water is at equilibrium or over-saturated with respect to fluorapatite and fluorite. The fluoride is mainly derived from the weathering of volcanic ash and obsidian, as well as from the thermal waters in the park. The high levels of fluoride and $\mathrm{SiO}_{2}$ measured in samples of ground water from the sites at Madison Junction and Old Faithful may be due in part to their proximity to thermal areas. The sites at Grant Village and Fishing Bridge, which are further removed from major thermal areas, have much lower levels of $\mathrm{SiO}_{2}$ and fluoride. This suggests that a portion of the fluoride and $\mathrm{SiO}_{2}$ at the Madison 
Junction and Old Faithful sites is derived from thermal waters, despite the apparent lack of influence of the thermal waters on the content of As and other trace metals in the ground waters at these two sites. Solubility controls limiting the concentration of dissolved fluoride in water include equilibrium with respect to fluorite for those waters containing sufficient $\mathrm{Ca}$, or the presence of strong fluoride complexes (Al, $\left.\mathrm{Fe}^{+3}, \mathrm{OH}\right)$ (Hem 1985). Adsorption of fluoride by gibbsite, kaolinite, halloysite, and especially for fresh $\mathrm{Al}(\mathrm{OH})_{3}$ precipitates may also affect fluoride concentrations (Hem 1985).

\section{VARIABILITY OVER TIME}

In general, concentrations of ground-water solutes are inversely related to the depth to the water table, showing an annual cycle which is a function of the amount of recharge that results largely from spring snowmelt. The conservative ions $\mathrm{Cl}$ and $\mathrm{SO}_{4}$ most closely parallel the changes in depth of the water table. The inverse relationships between watertable level and solute concentrations, in which a deeper water table corresponds to higher concentrations of solute ions and vice versa, are most clearly expressed in the ground water at the Grant Village site. A comparison of pre-burn chemistry relationships with water-table levels shows the latter to have a closer correlation. This may be the result of removal of biotic factors that influence ion uptake and redistribution. Without vegetation to alter and redistribute concentrations of nutrients, the solute concentrations are influenced mostly by mineralogical controls and physical processes such as dilution.

\section{BROMIDE TRACER STUDY}

Results from the $\mathrm{Br}$ tracer study indicate that none of the tracer solution has yet reached the water table, even in those areas with water table elevation at one to two meters below the ground surface (Madison Junction site). All samples analyzed had only background levels of $\mathrm{Br}$, as determined by pretracer analyses.

\section{ASH-EXTRACTION STUDIES}

The extractions performed on wood ash, collected from throughout the Park, have identified the chemical components of the ash, as well as their relative abundances. The ash contains large amounts of soluble material. Substantial amounts of some essential elements required by plants $(\mathrm{Ca}, \mathrm{Mg}, \mathrm{K}$, and $\mathrm{S}$ as $\mathrm{SO}_{4}$ ) are quickly released from the ash upon wetting. Some other nutrients (notably $\mathrm{PO}_{4}$ ) are not released until the ash has experienced more than one wetting event; possibly as the result of oxidation and degradation of the ash by microbes that remain inactive until the ash has been wet long enough to stimulate microbial growth. Trends seen in the results of the ash extractions include: (1) a trend for the concentrations of some ions to drop off sharply with successive extractions (eg. $\mathrm{SO}_{4}, \mathrm{~K}, \mathrm{Mg}$ ), (2) a fairly constant concentration for other ions (eg. $\left.\mathrm{SiO}_{2}\right)$, and (3) a trend of increasing levels of some other ions (eg. $\mathrm{PO}_{4}$ ) in some samples. These trends correspond to (respectively): (1) dissolution of soluble salts, (2) equilibrium with a solid phase present, and (3) possible oxidation and mineralization of organic components in the ash.

Fresh ash, collected in 1988 prior to any precipitation, contains high concentrations of watersoluble $\mathrm{Ca}, \mathrm{K}, \mathrm{Mg}, \mathrm{SiO}_{2}, \mathrm{SO}_{4}$, and in some cases, $\mathrm{NO}_{3}$. Alkalinity and $\mathrm{pH}$ of these fresh samples are also elevated with respect to values for the shallow, non-thermal ground waters of the park. Comparison of the leachate chemistry of ash samples collected from the same localities one year after the fires, with samples collected in 1988 show decreased concentrations of all the above constituents, probably due to leaching by precipitation. Samples collected one year after the fires (i.e. ash collected after one year of weathering in the natural environment) also released solutes upon leaching. This indicated that ashderived components continue to be leached from the ash for a number of wetting episodes after the fires. With successive extractions, the extracts from fresh ash (ash collected in 1988 immediately after the fires) show a shift in bulk composition, in terms of the relative proportions of cations and anions. The trend is not just dilution, but an actual shift in composition. In general, the concentrations of $\mathrm{SO}_{4}, \mathrm{Cl}$, and $\mathrm{F}$ decrease with each extraction, whereas concentrations of $\mathrm{NO}_{3}, \mathrm{NO}_{2}$, and $\mathrm{PO}_{4}$ increase. Concentrations of all cations decrease, and alkalinity usually decreases as well.

\section{CHARACTERIZATION OF SOILS}

Soil described at each of the four sites of ground-water sampling are weakly developed, with A over C horizons (Entisols) at three sites (Old Faithful, Madison Junction, Fishing Bridge), and an 
$\mathrm{A} / \mathrm{Bw} / \mathrm{C}$ profile (Inceptisol) at the Grant Village site. Soils are dominantly coarse-textured, consisting largely of obsidian and rhyolite sand and gravel, and sand and silt-sized sanidine and quartz. These components of the soil parent material provide the abundant silica measured in the ground water as $\mathrm{SiO}_{2}$. High-silica rhyolite and obsidian $\left(>75 \% \mathrm{SiO}_{2}\right)$ may also contain high levels of components such as fluorine (Burt et al. 1982), and are most likely responsible for the high levels of dissolved fluoride seen in water samples from some wells. The proportion of clay-size particles in all soil horizons is low and does not exceed seven percent in any sample. Percentage of organic matter was not determined, but can be estimated by the percentage loss of the 25 gram samples used for particle-size analysis. Using the values of percentage loss, organic matter constitutes a maximum of three to four percent for $A$ and Bw horizons, and one to two percent for $\mathrm{C}$ horizons. $\mathrm{X}$-ray diffraction analyses of the clay-sized fraction from each horizon of the profiles at the four sites gave inconclusive results. Although a sharp quartz peak was seen in the results for all samples, no other well-defined peaks were observed in any of the diffractograms. The youthfulness of the soils is probably responsible for the lack of well-crystallized phases, and, without sufficient long-range ordering, all phases would be classified as "amorphous," thereby defying identification by $\mathrm{x}$-ray diffraction analysis.

\section{LYSIMETER SAMPLES}

Results from 1990 samples show the movement of the wetting front (from snowmelt) downward through the unsaturated zone. At sites that experienced an early snowmelt (e.g. Madison Junction), no water was present and no samples were collected from the shallower (15 and $30 \mathrm{~cm}$ ) lysimeters. At the Old Faithful and Grant Village sites, more samples were collected from the 60 and $90 \mathrm{~cm}$ depths in June than in May. Snowmelt from the spring of 1991 was collected in about half of the lysimeters.

Following stabilization within the reconstructed soil profile around the lysimeters, the soil solutions contain $\mathrm{NO}_{3}$ as the dominant anion and $\mathrm{Ca}$ as the dominant cation. Concēntrations of $\mathrm{SiO}_{2}$ are substantially lower than those seen in the ground waters, and $\mathrm{pH}$ values average about 5.6 , the latter being consistent with values reported for soil solutions in lodgepole pine (Pinus contorta) ecosystems (Fahey and Knight 1986).
Solute composition of the soil solution has been suggested to be directly related to soil texture, with a strong biotic control for nitrogen and potassium (Fahey and Knight 1986). Fahey and Knight (1986) speculated that the low productivity of lodgepole pine forests may be due to a limited availability of nitrogen. Yavitt and Fahey (1986) measured total N concentrations in forest-floor solutions and found a high of about $5 \mathrm{mg} / \mathrm{L}$ during initial stages of snowmelt, which soon decreased to slightly less than $1 \mathrm{mg} / \mathrm{L}$. Soil solutions collected in our burned sites have $\mathrm{NO}_{3}$ concentrations ranging from 7 to $67 \mathrm{mg} / \mathrm{L}$, perhaps due to: (1) lack of nitrogen uptake by plants (all vegetation removed by burning), (2) infiltration of nitrogen-rich ash leachates, (3) addition of fire retardant, diammonium phosphate $\left(\mathrm{NH}_{4}\right)_{2} \mathrm{HPO}_{4}$, from the slurry bomber plane during the fires, (4) an increase in the activity of nitrifying bacteria, or (5) sandy soil. As noted earlier, soil textures observed in all four of our study sites are similar and dominated by sand plus gravel fractions.

Fahey and Knight (1986) concluded that "...biological activity plays a critical role in regulating the fluxes of water and major ions" thereby suggesting that an ecosystem which has had all vegetation removed by intense burning may experience marked changes in the flux of water and major ions. Knight et al. (1985) stated that, because "...nutrient retention in the snow-dominated lodgepole pine ecosystem appears to be primarily dependent on evergreen leaf area...," the "...losses of limiting nutrients probably occur primarily in pulses after abiotic perturbations such as fir., " which affect the leaf area index (LAI). A comparison of our results with those of Knight et al. (1985) shows similar concentrations of $\mathrm{P}, \mathrm{K}, \mathrm{Na}, \mathrm{Mg}$, and $\mathrm{Ca}$, but dissimilar levels of nitrogen, with our nitrogen values two orders of magnitude greater than theirs. High concentrations of $\mathrm{NO}_{3}$ in some ash leachates suggest that ash-derived nitrogen, or possible a post-fire increase in the activity of nitrifying bacteria, may be responsible for the elevated nitrogen concentrations measured in the soil solutions.

\section{COMPUTER MODELING}

The geochemical computer models employed for this study are based on the assumption that equilibrium conditions are achieved between the solid and aqueous phases. Although this assumption may not be completely accurate (Lindberg and Runnells 
1984), it still offers the best approximation for an aqueous system in which the interpretations are based largely on the chemistry of dilute natural waters.

The simplest case of rock-water interaction determining water composition is equilibrium dissolution/precipitation. Other possibilities include: mixing of waters of two different compositions to produce the final, observed water chemistry; chemical reactions of cation exchange as well as adsorption and desorption of dissolved ions; and, biological factors that may influence or alter the water chemistry. Some or all of these processes may be involved in affecting the chemical composition of the water sampled for study. The computer programs used in this study can model all but the latter factor the biological factor. The influence of the biologic factor can only be evaluated during interpretation of the analytical and modeling results.

Three types of calculations are used to describe the geochemistry of the ground-water system (Plummer 1984). Speciation calculations, based on thermodynamic and analytical data, provide a measure of the tendency of a particular mineral to dissolve or precipitate in a given aqueous system. The distribution of dissolved species (ions and ionpairs) is also computed, as well as the speciated and unspeciated charge balance.

Mass-balance calculations constrain the changes in the chemical composition of water along the flow path, based on the conservation of mass. This type of calculation requires knowledge of the composition of the initial and final waters along the flow path, and at least a general idea of which mineral phases are present and interacting with the water as it migrates along the path. The possible reactions computed by the model are not constrained by thermodynamic data, so they must be checked for feasibility prior to acceptance of the reaction model produced by the mass-balance calculations.

Following the development of several models based on mass-balance calculations, the feasibility and validity of the models can also be checked using a mass-transfer program. Mass-transfer calculations employ a thermodynamic model of the mineral-water system, and predict solution composition and transfers among the aqueous, gaseous, and solid phases of the system. Some mass-transfer programs (e.g. MINTEQA2) include algorithms for a variety of calculations. Mass-balance modeling, using NETPATH (Plummer 1991) is currently in progress.

\section{SPECIATION AND EQUILIBRIA CALCULATIONS}

Truesdell and Jones (1974) developed the original WATEQ program for the calculation of chemical equilibria in dilute natural waters at surface temperatures. Since the formulation of the original WATEQ computer program in 1974, the WATEQ family of geochemical modeling programs has grown to include an interactive BASICA revision for IBMtype personal computers, WATEQB (Arikan 1988). WATEQB, along with other geochemical modeling programs such as MINTEQA2, employs approximately the same thermodynamic database as WATEQF (Plummer et al 1976) and permits rapid calculation of the equilibrium distribution for inorganic aqueous species. Approximately 270 complete analyses of aqueous samples were performed throughout the course of this study. All of these analyses have been run for speciation and equilibria calculations using the computer program WATEQB (Arikan 1988). Taking a range of saturation index (SI) values between $+/-0.500$ to indicate equilibrium with respect to a given solid phase and values of SI>0.500 to indicate oversaturation with respect to a given solid phase, virtually all samples of ground water are oversaturated with respect to forms of $\mathrm{SiO}_{2}$ (silica gel, silica glass, chalcedony, quartz). High concentrations of fluoride in many of the ground-water samples cause the waters to be oversaturated with respect to minerals such as fluorite and fluorapatite. Results from the runs of WATEQB assist in the selection of suitable phases to be used as input in the mass-balance and mass-transport modeling.

\section{MASS-BALANCE CALCULATIONS}

NEPATH is an interactive computer program for determining "...net geochemical mass-balance reactions between an initial and final water along a hydrologic flow path." (Plummer et al. 1991). This model is the successor to the program BALANCE (Parkhurst et al. 1982) and extends the capabilities of the model to include mixing of waters and ionexchange, in addition to dissolution and precipitation of specified mineral phases. NETPATH also allows the user to specify that certain phases must be included in every possible model ("forced") and that 
specific phases be available for dissolution-only, precipitation-only, or both. Additional components and phases may be specified by the user and added to the program database. Using mineral saturation and ionic speciation results obtained from runs of WATEQB, as well as mineralogical data from samples of soil and regolith collected at the sites of ground-water sampling, a large number of possible models were tested by NETPATH. Because the solutions are not unique, a number of reasonable models may be accepted for further testing.

\section{IMPLICATIONS FOR MANAGEMENT}

Although the forest fires of 1988 were widespread and dramatic, the impact on ground-water chemistry appears to be minimal. Hydrologic changes, such as earlier and more rapid snowmelt due to decreased shading by vegetation, can be expected in areas affected by crown fires and heavy burning. Increased soil temperatures, due to increased solar radiation reaching the forest floor, will probably be found in areas subjected to crown fires. Such temperature increases will favor an increase in microbial activity, such as that of nitrifying bacteria (Ahlgren 1974). These bacteria are probably responsible for the high concentrations of $\mathrm{NO}_{3}$ measured in the soil solutions at the severely-burned site (Grant Village).

Despite the dilute nature of non-thermal ground water in the Park, no major alterations in the chemistry of ground water have yet been confirmed. The lack of pronounced changes in the post-fire ground-water chemistry, as determined by analysis of ground-water samples collected over the past two years and comparison with pre-fire data, suggests several possibilities. It is possible that the assimilative capacities of the soil and rock substrate serve to attenuate the impact that large quantities of ashderived solubles could have on the chemistry of ground water. Assimilation of ash-derived solubles could occur by sorption of solute ions onto the solid substrate or by precipitation of mineral phases. Other possibilities, including minimal infiltration of an ash-leachate due to rapid removal of ash-derived solubles during surface runoff, should also be considered. Evaluation of the results of lysimeter data (soil-water analyses) may assist in confirming or dispelling this latter possibility.

Continuing graphical and computer analysis of the chemical data will better define and quantify the character and extent of changes in the chemical and physical properties of non-thermal ground waters in the Park.

\section{$\checkmark \quad$ LiteratURE CITED}

Ahlgren, I. F. 1974. The effect of fire on soil organisms. pp. 47-72 In: Fire and Ecosystems, T. T. Kozlowski, and C. E. Ahlgren, (eds.), Academic Pres.

Arikan, A. 1988. WATEQB - BASICA revision of WATEQF for IBM personal computers. Ground Water, v. 26, n. 2, p. 222-227.

Burt, D. M., M. F. Sheridan, J. V. Bikun, and E. H. Christiansen. 1982. Topaz rhyolitedistribution, origin, and significance for exploration. Economic Geology 77:1818-1836.

Cox, E. R. 1986. Wastewater movement near four treatment and disposal site in Yellowstone National Park, Wyoming. U.S. Geological Survey Water-Resources Investigations Report 84-4356, 81 p.

Dirks, R. A. and B. E. Martner. 1982. The climate of Yellowstone and Grand Teton National Parks. National Park Service Occasional Paper Number Six, 26 p.

Fahey, T. J. and D. H. Knight. 1986. Lodgepole pine ecosystems. BioScience 36:610-617.

Hem, J. D. 1985. Study and Interpretation of the Chemical Characteristics of Natural Water. U.S. Geological Survey Water-Supply Paper 2254, 263 p.

Knight, D. H., T. J. Fahey, and S. W. Running. 1985. Water and nutrient outflow from contrasting lodgepole pine forests in Wyoming. Ecol. Mon. 55:29-48.

Lindberg, R. D. and D. D. Runnells. 1984. Ground water redox reactions: an analysis of equilibrium state applied to Eh measurements and geochemical modeling. Sci. 225:925-927. 
Parkhurst, D. L., D. C. Thorstenson, and L. N. Plummer. 1980. PHREEQUE computer program. U.S. Geological Survey WaterResources Investigations, 80-96, 210 p.

Parkhurst, D. L. L. N. Plummer, and D. C. Thorstenson. 1982. BALANCE computer program. U.S. Geological Survey WaterResources Investigations 82-14, 216 p.

Plummer, L. N., B. F. Jones, and A. H. Truesdell. 1976. WATEQF - A FORTRAN IV version of WATEQ, a computer program for calculating chemical equilibrium in natural waters. U.S. Geological Survey Water Resources Investigations 76-13, $61 \mathrm{pp}$.

Plummer, L. N., E. C. Prestemon, and D. L. Parkhurst. 1991. An interactive code (NETPATH) for modeling net geochemical reactions along a flow path. U.S. Geological Survey, in press.

Plummer, L. N. 1984. Geochemical modeling: a comparison of forward and inverse methods; pp. 149-177 In: Proceedings of the First Canadian/American Conference on Hydrogeology, B. Hitchon, and E. I. Wallick, (eds.), National Water Well Association.
Stauffer, R. E., E. A. Jenne, and J. W. Ball. 1980. Chemical studies of selected trace elements in hot-spring drainages of Yellowstone National Park. U.S. Geological Survey Professional Paper 1044-F, 20 pp.

Thurman, E. M. 1985. Organic Geochemistry of Natural Waters. Martinus Nijoff/Dr W. Junk Publishers, 497 pp.

Truesdell, A. H., and B. F. Jones. 1974. WATEQ, a computer program for calculating chemical equilibria of natural waters. U.S. Geological Survey J. Res. 2:233-248.

U.S. Environmental Protection Agency. 1989. MINTEQA2, an equilibrium metal speciation model.

Yavitt, J. B., and T. J. Fahey. 1986. Litter decay and leaching from the forest floor in Pinus Contorta (Lodgepole pine) ecosystems. J. Ecol. 74:525-545. 